\title{
Fluoride concentrations in groundwater and impact on human health in Siloam Village, Limpopo Province, South Africa
}

\author{
John Ogony Odiyo* and Rachel Makungo \\ University of Venda, Department of Hydrology and Water Resources, P/Bag X 5050, Thohoyandou 0950, South Africa
}

\begin{abstract}
Monitoring of fluoride concentrations in groundwater, identification of sources, and monitoring of the impact of fluoride on human health was undertaken in Siloam Village, Limpopo Province, South Africa. Most of the inhabitants of Siloam Village rely on groundwater for domestic use due to inadequate pipe-borne water supply. A preliminary survey showing that some community members in Siloam Village have mottled teeth motivated the study. Temperature and $\mathrm{pH}$ were measured in the field while fluoride and calcium in groundwater were analysed in the laboratory. A survey was conducted to obtain information on the impact of fluoride on human health. $40 \%$ of the households and 1 primary school in Siloam Village were interviewed. Fluoride concentrations in groundwater samples were found to be higher than the Department of Water Affairs and World Health Organization recommended values for domestic use of $1 \mathrm{mg} / \ell$ and $1.5 \mathrm{mg} / \ell$, respectively. The results of paired two-tailed t-tests showed significant differences between mean values of $\mathrm{pH}$, temperature, calcium and fluoride concentrations for all paired comparisons between 3 sites, with the exception of comparisons between sites GW1 (community borehole) and GW2 (artesian spring). Alkaline $\mathrm{pH}$, low calcium concentrations, high groundwater temperatures and semi-arid climatic conditions of the study area may cause elevated fluoride concentrations in groundwater, by increasing the solubility of fluoride-bearing formations (fluorite). A survey revealed that $87 \%$ of the households use groundwater while $85 \%$ of these have family members with mottled teeth. 50\% of children between the ages of 11 and 14 in Siloam Primary School also have mottled teeth. There is thus evidence suggesting negative human health impacts of high fluoride concentrations in groundwater in Siloam Village. The majority of the community was found to be aware of the fluorides in groundwater and the health impacts thereof making interventions easy to promote.
\end{abstract}

Keywords: Fluorides, groundwater, impacts, human health, Siloam Village

\section{Introduction}

Groundwater is the most widely used source of drinking water in many rural communities in South Africa. Due to relatively arid conditions prevailing in Limpopo Province, $75 \%$ of the population has been shown to be dependent on groundwater as a source of water supply (Botha and Van Rooyen, 2001). This is despite the fact that groundwater in most parts of South Africa is known to have high concentrations of fluoride causing a preponderance of dental fluorosis (WHO, 2000; Bailey et al., 2006; Rivett et al., 2006; Feenstra et al., 2007). North West, Limpopo, and Northern Cape have been identified as provinces displaying high levels of fluorides in groundwater, often as high as $30 \mathrm{mg} / \ell$ (WHO, 2000). Siloam Village is an example of a rural village in South Africa dependent on untreated groundwater for domestic use due to inadequate pipe-borne water supply. A preliminary survey showing that some of the community members in Siloam Village have mottled (discoloured) teeth motivated this study.

Ncube and Schutte (2005) indicated that there is lack of adequate information on the status of fluoride in the country's groundwater resources and on the environmental and health impacts of fluoride. They assessed groundwater fluoride data from the Department of Water Affairs and Forestry's Water Management System database for the period 1996-2000, in order to establish the distribution of fluoride ion concentrations in groundwater and the impact of dietary fluoride on dental health in South Africa. Median fluoride values of groundwater

\footnotetext{
* To whom all correspondence should be addressed.

용 +27 15 962-8568; fax: +27 15 962-8597;

e-mail: john.odiyo@univen.ac.za

Received 4 July 2010; accepted in revised form 27 September 2012.
}

sources were plotted on a GIS map to assess fluoride distribution across South Africa. The results indicated that the problem of high fluoride ion concentrations is prevalent in Limpopo, Northern Cape, North-West and KwaZulu-Natal Provinces, where large populations still live in rural areas and mostly use groundwater for drinking purposes. The current study assessed fluoride concentrations in groundwater at Siloam Village for the periods August-October 2006 and January-May 2007. Thus, the current study provides more detailed information on actual fluoride concentrations in the study area. The occurrence of dental fluorosis in the Free State, North West, KwaZulu-Natal and Western Cape Provinces was also assessed by Ncube and Schutte (2005) - Limpopo Province was omitted from this survey.

McCaffrey and Willis (2001) investigated the distribution of fluoride-rich groundwater in the North-West and Limpopo Provinces of South Africa. High fluoride concentrations in groundwater were attributed to several causes, including high fluorine content of aquifers, low groundwater flow rates, an arid and semi-arid climate increasing potential evaporation, and water with a high $\mathrm{pH}$. Though the study covered northern regions of South Africa, it excluded Siloam Village.

The current study has investigated fluoride concentrations in Siloam Village, as an example of a typical rural village in South Africa with high fluoride concentrations, the likely sources of fluoride, the factors affecting concentration and the impacts on human health. Earlier studies, such as Mashai (2007) and Odiyo and Makungo (2009), have shown high concentrations of fluoride in groundwater at Siloam Village. The study aimed at providing detailed, precise, accurate and reliable information on fluoride concentrations in Siloam Village. Such a study provides site-specific information that can be used to infer the scale of risk at the point of use and can therefore aid in planning 


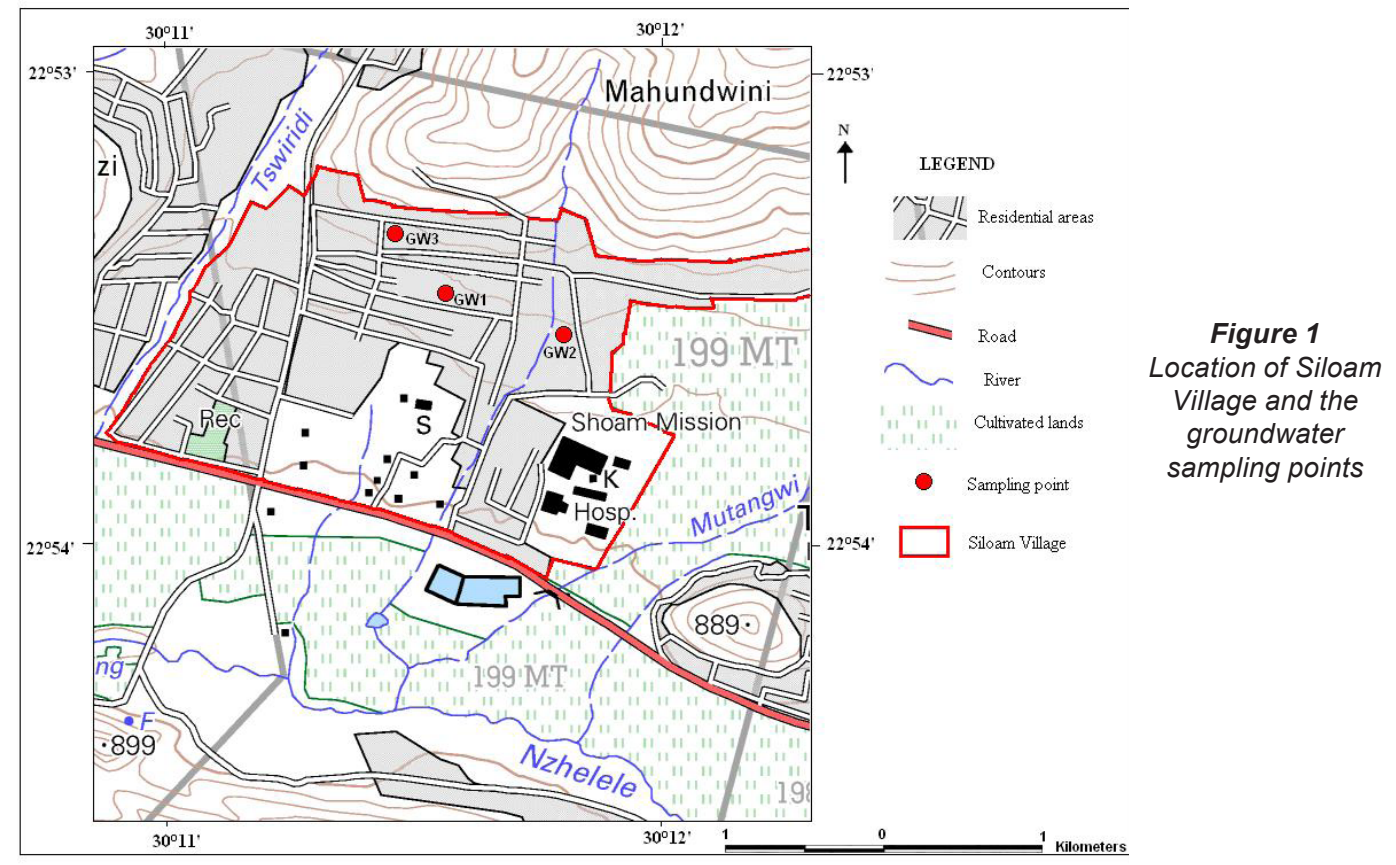

appropriate intervention measures, unlike studies focused on wide geographical areas, which may not give site-specific representative distributions of fluorides and fluoride-related health problems.

In Siloam Village, groundwater is frequently used without treatment exposing the residents to excessive concentrations of fluoride. Groundwater does not form part of the bulk water supply to the village, and thus there is no provision for treatment. The bulk water supply from the communal stand pipes is, however, inadequate leading to communities using untreated groundwater. The community borehole provided by the municipality for groundwater supply on a small scale has never warranted a treatment plant and hence the community is left vulnerable to high concentrations of fluoride. There is also a widespread belief that groundwater is relatively safe from contamination, a fact that ignores geochemical pollution from the parent rock which constitutes the groundwater aquifer.

\section{Study area}

Siloam Village falls under quaternary catchment A80A of the Nzhelele River catchment which is located in the northern region of Limpopo Province, South Africa. The study area is found between latitudes $22^{\circ} 53^{\prime} 15.8^{\prime \prime} \mathrm{S}$ and $22^{\circ} 54^{\prime} 5^{\prime \prime} \mathrm{S}$ and longitudes $30^{\circ} 11^{\prime} 10.2^{\prime \prime} \mathrm{E}$ and $30^{\circ} 11^{\prime} 23.5^{\prime \prime} \mathrm{E}$ (Fig. 1). Figure 1 shows the location of Siloam Village and the groundwater sampling points.

\section{Methods}

Groundwater samples were collected twice a month from the community borehole and an artesian spring from August to November 2006, and once a month from the community borehole, an artesian spring and a private borehole from January to May 2007. An extra sampling point (a private borehole) was included during the January-May 2007 sampling period in order to assess the spatial distribution of fluorides in groundwater. The 2 sampling periods were used to assess fluoride concentrations in the dry and wet seasons. Three samples were collected at each site and analyses were conducted in triplicate and the mean value calculated. The mean of the values from the 3 samples at each sampling site was recorded as the concentration/value for that particular month. The standard error of measurement (SEM) of the mean was computed to determine the reliability of the measured results.

Temperature and $\mathrm{pH}$ were measured in the field using a Multi 340i multimeter supplied by Wissenschaftlich Technische Werkstätten. The ion selective electrode method was used to analyse fluoride concentrations for the samples collected from August to October 2006. Concentrations of fluoride and calcium in groundwater samples collected from January to May 2007 were analysed using Intelligent 850 Professional Ion Chromatography (IC) supplied by Metrohm. Analysis with an Ion Selective Electrode was done at the University of the Witwatersrand before the IC was bought at the University of Venda. All of the equipment was calibrated following the manufacturer's guidelines. It was important to measure temperature, $\mathrm{pH}$ and calcium as they influence the concentration of fluorides in groundwater. The mean fluoride concentration for each sampling site was compared with the DWAF (1996) guidelines for domestic use to assess compliance.

The SEMs of the means for the period of analysis (AugustOctober 2006 and January-May 2007) for all sampling sites were also computed and the error bars plotted to infer the statistical significance of their means and to show the spatial variation of the mean concentration of each parameter across sampling sites. Paired two-tailed t-tests were used to confirm if there was a significant difference between the means recorded for each parameter between any 2 sampling sites (samples were paired between sites based on the time of sampling).

A community survey was conducted to obtain information on the extent of the impact of fluoride on human health in Siloam Village. Approximately $40 \%$ of the households ( 150 out of 400 ) and $100 \%$ of school learners (189 out of 189) from a primary school in Siloam Village were interviewed. A sample size of at least $40 \%$ is recommended by Salkind (1997), among others, to ensure a representative sample. One person per household was interviewed. The random sampling technique was followed when conducting the questionnaire survey. The questionnaire was used to obtain information on the number 
of households and school learners who use groundwater, the number who have mottled teeth, and the general awareness and knowledge of treatment of mottled teeth. The percentages of households and learners who use groundwater, have mottled teeth, and displayed a general awareness of mottled teeth and knowledge of the treatment for mottled teeth were calculated.

\section{Results and discussion}

\section{Fluoride concentrations and their sources}

Figures 2-5 give the mean fluoride and calcium concentrations, $\mathrm{pH}$ and temperature in groundwater sampled from the community borehole (GW1), an artesian spring (GW2) and private borehole (GW3) for the periods August-November 2006 and January-May 2007, and their standard error bars (red lines). The SEM bars for all of the sampling sites are short indicating high precision of the measurements (Cumming et al., 2007).

The mean fluoride concentrations for GW1, GW2 and GW3 are 5.1, 5.6 and $1.7 \mathrm{mg} / \ell$, respectively (Fig. 6). The fluoride concentrations at all of the sampling points were higher than the DWAF (1996) and WHO (2006) guidelines for domestic use of $1 \mathrm{mg} / \ell$ and $1.5 \mathrm{mg} / \ell$, respectively. Fluoride concentrations exceeding $1.5 \mathrm{mg} / \ell$ cause dental mottling with associated tooth damage due to softening of enamel, while concentrations exceeding $4 \mathrm{mg} / \ell$ cause severe tooth damage (especially to the temporary and permanent teeth of infants), softening of the enamel and dentine and skeletal fluorosis, especially with continuous use of water (DWAF, 1996). Thus, the fluoride concentrations recorded in groundwater in Siloam Village constitute a major health risk. The results indicate persistence of high fluoride concentrations in groundwater even during the wet season when dilution occurs (Fig. 2). The fluoride concentrations at GW3 were, however, lower than the concentrations at GW1 and GW2. GW1 and GW2 are the main sources of groundwater for Siloam Village; thus high fluoride concentrations in groundwater from these sites constitute a major health risk to the majority of Siloam Village community members, though water from GW3 also contains fluoride concentrations $>1.5 \mathrm{mg} / \ell$. Residents of Siloam Village who rely on groundwater are therefore vulnerable to fluorosis. Figure 2 shows that fluoride concentrations at GW1 decreased during the wet season (October-March) and increased to a level of slightly greater than $5 \mathrm{mg} / \ell$ during part of the dry period (April-May 2007). Similar levels of fluorides were recorded in part of the dry period of 2006 (AugustSeptember).This shows the effects of dilution and concentration associated with the wet and dry seasons, respectively.

The mean calcium concentrations for GW1, GW2 and GW3 were 4.4, 2.4 and $70.4 \mathrm{mg} / \ell$, respectively. Calcium concentrations for GW1 and GW2 were lower than that for GW3 (Fig. 7). Low calcium concentrations increase the solubility of $\mathrm{CaF}_{2}$ which increases the concentration of fluorides in groundwater. Chae et al. (2007) reported that the thermodynamic relationship between $\mathrm{Ca}^{2+}$ and $\mathrm{F}^{-}$ions indicates that fluoride concentration is controlled by equilibrium of fluorite. When the water is saturated with respect to fluorite or is at equilibrium with fluorite, the low calcium concentration leads to higher fluoride concentrations (Nezli et al., 2009). High fluoride concentrations are therefore expected in groundwater from aquifers with low calcium concentrations. In groundwater with a high concentration of calcium, fluoride concentration rarely exceeds $1 \mathrm{mg} / \ell$ (Rivett et al., 2006).

Figure 8 shows the relationship between calcium and fluoride concentrations at the 3 sites sampled. The calcium

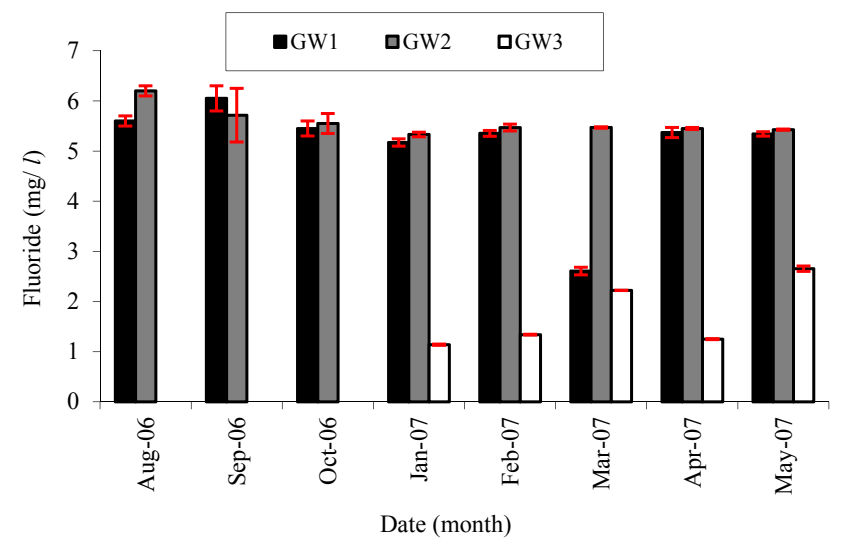

Figure 2

Fluoride concentrations for the period August-October 2006 and January-May 2007

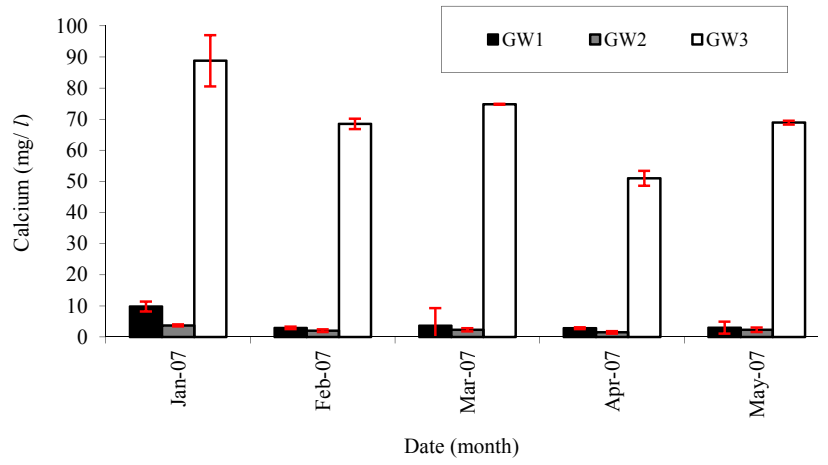

Figure 3

Calcium concentrations for the period January-May 2007

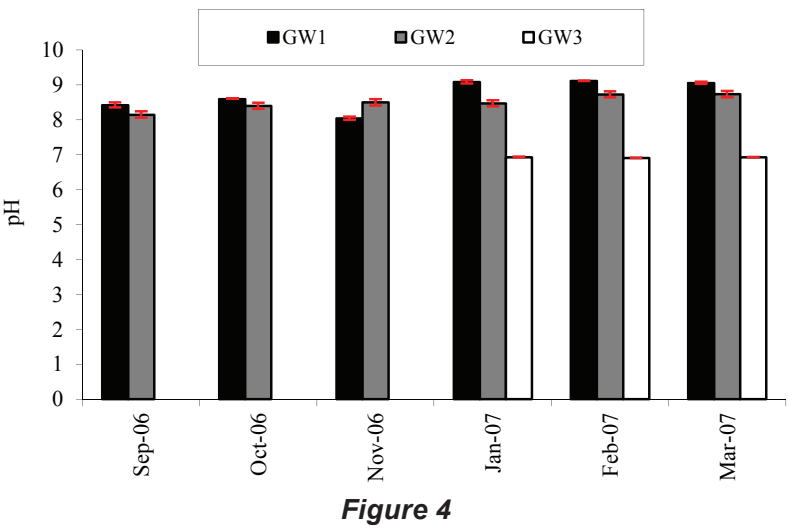

$\mathrm{pH}$ values for the period November-October 2006 and January-March 2007

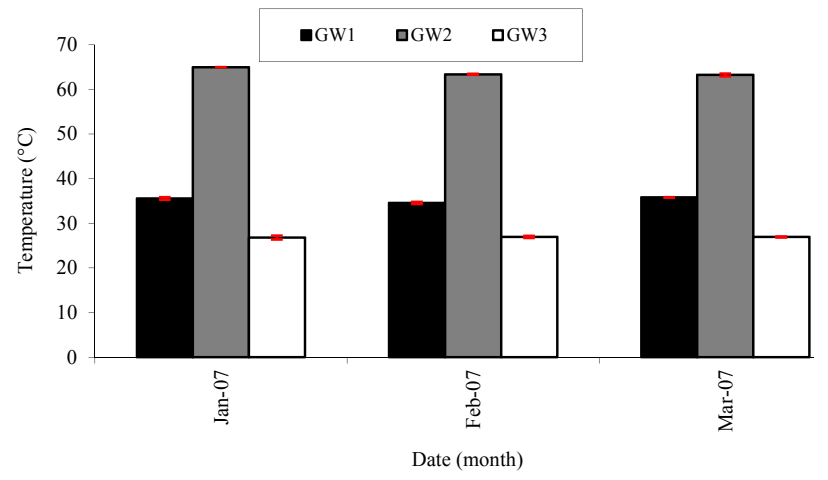

Figure 5

Temperature values for the period January-March 2007 


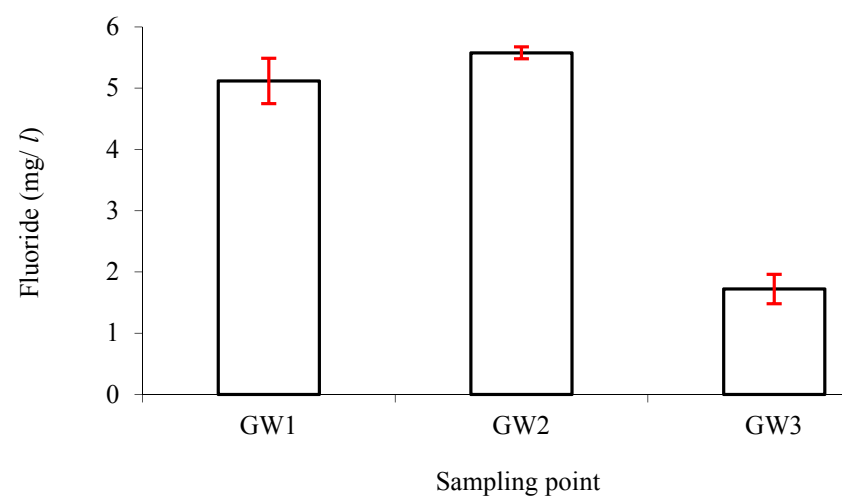

Figure 6

Mean fluoride concentrations

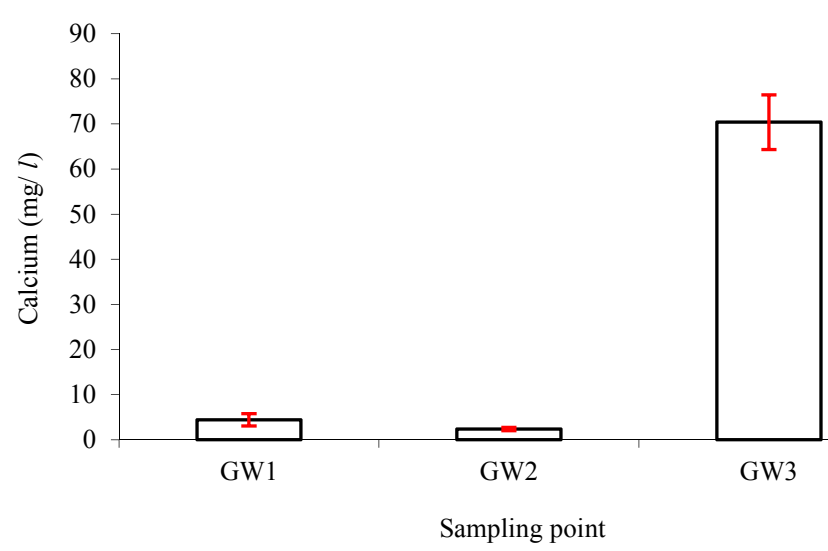

Figure 7

Mean calcium concentrations

concentration at GW1, for example, increased from $2.93 \mathrm{mg} / \ell$ in February to $24.97 \mathrm{mg} / \ell$ in March 2007 (Fig. 8). This caused a decrease in fluoride concentration from 4.45 to $2.61 \mathrm{mg} / \ell$ (Fig. 8) during the same period. The results generally show that increase in calcium is associated with decrease in fluoride and vice versa. The results show that the spatial and temporal variations of fluoride depend on the calcium concentration in groundwater.

Fluorite is a common fluoride mineral of low solubility occurring in both igneous and sedimentary rocks (Bailey et al., 2006). The main geological formations in the study area include sandstone, dark red shale and basalt of the Nzhelele formation. Two major rock-forming fluorine-bearing minerals exist: topaz $\left[\mathrm{Al}_{2}\left(\mathrm{SiO}_{4}\right)(\mathrm{OH}, \mathrm{F})_{2}\right]$ and fluorite $\left(\mathrm{CaF}_{2}\right)$ (McCaffrey and Willis, 2001; Näslund and Snell, 2005). McCaffrey and Willis (2001) reported that $\mathrm{CaF}_{2}$ is the most abundant fluoride-bearing mineral in the Limpopo Province (then named the Northern Province) of South Africa. The likely source of fluoride in Siloam Village is thus also $\mathrm{CaF}_{2}$.

The mean $\mathrm{pH}$ values for GW1, GW2 and GW3 were 8.7, 8.4 and 6.9, respectively (Fig. 9). The mean $\mathrm{pH}$ values for both GW1 and GW2 are for the periods September-November 2006 and January-March 2007, while the mean pH value for GW3 is for the period January-March 2007. The period SeptemberNovember falls partly in both the dry and wet seasons while January-March is in the wet season. In groundwater with $\mathrm{pH}>8$ and dominated by sodium ions and carbonate species, fluoride concentrations commonly exceed $1 \mathrm{mg} / \ell$, and concentrations in excess of $50 \mathrm{mg} / \ell$ have been recorded in South Africa (Rivett et al., 2006). Areas of clay-rich soils with high sodium content

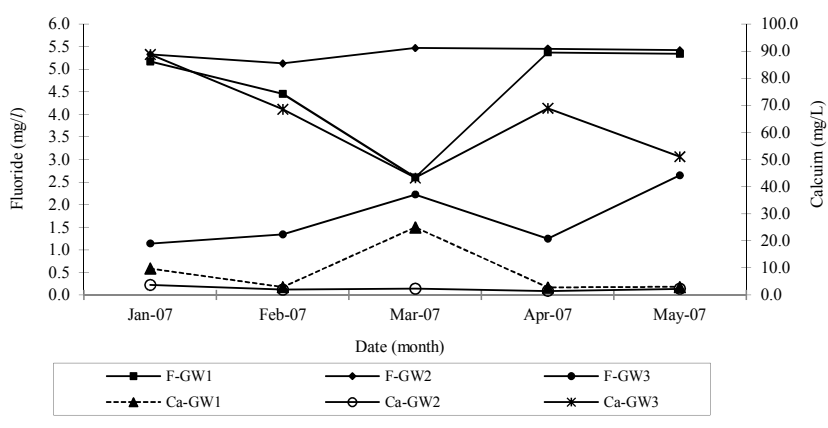

Figure 8

Fluoride and calcium concentrations for the period January-May 2007

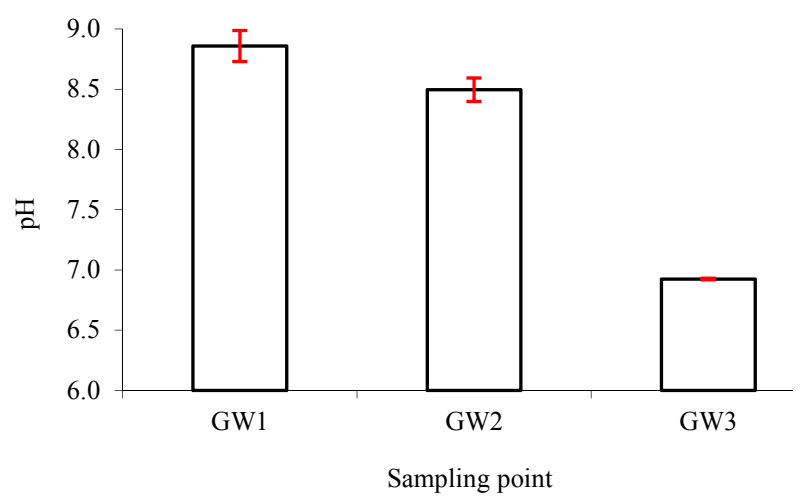

Figure 9

Mean $\mathrm{pH}$ values

lining internal drainage areas close to the Limpopo River are found within the Nzhelele area (Ashton et al., 2001) where Siloam is located. Weathering and leaching of fluoride-bearing minerals in rock formations under alkaline environments lead to the enrichment of fluoride in groundwater (Raju et al., 2009). This is because decreased calcium concentrations occur under alkaline conditions (Jacks et al., 2005), which increases the solubility of fluoride-bearing formations thereby increasing fluoride concentrations in groundwater. A study by Saxena and Ahmed (2003) showed that an alkaline $\mathrm{pH}$ ranging from 7.4 to 8.8 resulted in high fluoride concentrations $(1.7$ to $6.1 \mathrm{mg} / \ell)$ in groundwater sources in India. Alkaline pHs which increased the solubility of fluoride-bearing formations likely contributed to increased fluoride concentrations at GW1 and GW2 in this study.

The mean temperatures at GW1, GW2 and GW3 for January-March 2007 were $35.3,63.86$ and $26.9^{\circ} \mathrm{C}$, respectively (Fig. 10). The high temperatures at GW2 indicate that it is a thermal spring. Olivier et al. (2008) found that a number of thermal springs in the Waterberg area of the Limpopo Province of South Africa have high concentrations of fluoride. High temperatures increase the solubility of fluoride-bearing formations thereby increasing the fluoride concentrations in groundwater. Thermal waters, especially those of high $\mathrm{pH}$, are rich in fluoride (Edmunds and Smedley, 1996). Though the temperature values for GW2 are higher than those for GW1, their fluoride concentrations throughout the sampling period are generally high and comparable (Fig. 2). This is likely to be due to the fact that their calcium concentrations and $\mathrm{pHs}$ are also generally low and high, respectively, and comparable (see Figs. 3 and 4), resulting in high fluoride concentrations. GW3 has relatively low temperatures (Fig. 5) associated with low fluorides availability as observed in Fig. 2. The fluoride concentrations in the artesian 


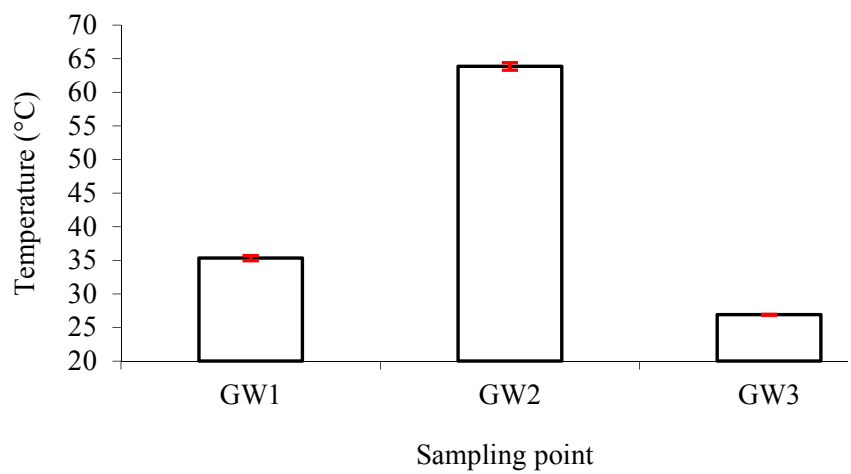

Figure 10

Mean temperature values

spring (GW2) seem to not be seriously affected by the variation in rainfall between wet and dry seasons (Fig. 2). This can be attributed to the fact that groundwater in the spring appears to be originating from the deep layers of the aquifer where temperatures are very high.

Studies such as Vasak et al. (2006) and Madhnure et al. (2007) have indicated that arid climates characterised by high evaporation rates are associated with high fluoride concentrations in groundwater. In arid/dry conditions groundwater flow is low and the reaction time of groundwater with the rock is long (Vasak et al., 2006). This creates more time for dissolution of the fluoride-bearing formations. High evaporation rates (associated with high temperatures) reduce the amount of rainwater available to recharge the groundwater aquifers thereby reducing the dilution effect of surface water on groundwater chemical composition. These climatic conditions apply to Siloam Village which is located on the leeward side of the Soutpansberg Mountains and is semi-arid with low and unpredictable rainfall (average 350-400 $\mathrm{mm} / \mathrm{a}$ ), high temperatures and high evaporation rates (1 300-1 $400 \mathrm{~mm} / \mathrm{a})$. Thus, the climatic conditions at Siloam Village result in a reduced dilution effect on groundwater chemical composition, and increased fluoride concentrations.

The SEM bars for all of the sampling sites for the period of analysis are shown in Figs. 6, 7, 9 and 10. The SEM bars were plotted to check whether the variations in the mean values are statistically significant. The SEM bars for all of the figures (Figs. 6, 7, 9 and 10) do not overlap, with the exception of mean fluoride valuess for GW1 and GW2. Non-overlapping SEM bars do not indicate the presence or absence of statistical significance (Motulsky, 2007). Overlapping SEM bars indicate a lack of significance, where sample sizes are equal or nearly equal (Motulsky, 2007). Thus, based on the SEM bars (Fig. 6), there is no significant difference between the mean fluoride concentrations for GW1 and GW2 (sample sizes were equal for all of the sites).

A two-tailed test was necessary to confirm whether there is any significant difference between the means of the other variables measured for all of the sampling sites. The results of the paired two-tailed test are shown in Table 1 . There was a significant difference $(p<0.001)$ between mean fluoride concentrations for GW2 and GW3, mean calcium concentrations for GW1 and GW3, and GW2 and GW3, mean $\mathrm{pH}$ for GW1 and GW3 and mean temperature for GW1 and GW3, and GW2 and GW3 (Table 1). Mean temperature was significantly different $(0.001<p<0.01)$, and mean $\mathrm{pH}$ was significantly different $(0.01<p<0.05)$ between GW1 and GW2, whereas there was no significant difference $(p>0.05)$ between the fluoride and calcium concentrations at these sites. Mean fluoride concentration differed significantly $(0.01<p<0.05)$ between GW1 and GW3, and pH differed significantly $(0.001<\mathrm{p}<0.01)$ between GW2 and GW3.

\section{Evaluating the impacts of fluorides on human health}

The results of the questionnaire survey conducted in Siloam Village to evaluate the impact of fluorides on human health are shown in Tables 2 and 3. The sample size represents the number of households $(\mathrm{HH})$ or school leaners that were interviewed in the current study. The results show that of the $87 \%$ of households that use groundwater, $85 \%$ have members with mottled teeth. $50 \%$ of school learners between the ages of 11 and 14 also have mottled teeth.

$52.7 \%$ of the respondents indicated that $1-5$ people in their households had mottled teeth; $91 \%$ of the respondents have neighbour(s) with mottled teeth while $77.3 \%$ are aware of the presence of mottled teeth in residents of Siloam Village (Table 3). The results of the survey also showed that residents of Siloam Village are aware of the problems associated with the use of groundwater containing high fluoride levels and $80 \%$ of the respondents have knowledge about treatment of mottled teeth (Table 3). Lack of a reliable and adequately-treated water supply forces the residents to resort to the use of untreated groundwater.

\section{Conclusion}

Groundwater sources in Siloam Village have fluoride concentrations exceeding the DWAF (1996) guidelines for domestic use.

\begin{tabular}{|c|c|c|c|c|}
\hline \multicolumn{5}{|c|}{$\begin{array}{c}\text { Table } 1 \\
\text { Results for the paired two-tailed t-test ( } p \text { values) }\end{array}$} \\
\hline Site & $F$ & $\mathrm{Ca}$ & $\mathrm{pH}$ & Temperature \\
\hline GW1 and GW2 & $0.23717^{\mathrm{ns}}$ & $0.11247^{\text {ns }}$ & $0.01958^{*}$ & $0.00233^{* *}$ \\
\hline GW1 and GW3 & $0.01313^{*}$ & $0.00010^{* * * *}$ & $0.00002^{* * *}$ & $0.00042^{* * *}$ \\
\hline GW2 and GW3 & $0.00046^{* * *}$ & $0.00029^{* * *}$ & $0.00272^{* *}$ & $0.00027^{* * *}$ \\
\hline
\end{tabular}

\begin{tabular}{|l|c|c|c|c|}
\hline \multicolumn{5}{|c|}{ Results of questionnaire survey conducted in Siloam Village } \\
\hline Sample type & $\begin{array}{c}\text { Sample } \\
\text { size }\end{array}$ & $\begin{array}{c}\text { Total } \\
\text { population }\end{array}$ & $\begin{array}{c}\% \text { using } \\
\text { groundwater }\end{array}$ & $\begin{array}{c}\% \text { using groundwater and have } \\
\text { mottled teeth }\end{array}$ \\
\hline Households & 150 & 400 & 87 & 85 \\
\hline School learners & 189 & 189 & 100 & 50 \\
\hline
\end{tabular}




\begin{tabular}{|l|l|l|}
\hline \multicolumn{2}{|c|}{$\begin{array}{c}\text { Table } 3 \\
\text { Problems, awareness and knowledge of treatment of } \\
\text { mottled teeth }\end{array}$} \\
\hline & & \% of respondents \\
\hline $\begin{array}{l}\text { Number of people } \\
\text { in household with mot- } \\
\text { tled teeth }\end{array}$ & $1-5$ & 52.7 \\
\cline { 2 - 3 } & $6-10$ & 28.7 \\
\cline { 2 - 3 } & $11-15$ & 10 \\
\cline { 2 - 3 } & 16 and more & 8.7 \\
\hline Neighbours with mottled teeth & 91 \\
\hline General awareness of mottled teeth & 77.3 \\
\hline Knowledge of treatment of mottled teeth & 80 \\
\hline
\end{tabular}

The likely source of fluorides is fluorite mineral which is found in igneous and sedimentary rocks dominant in the study area. Alkaline $\mathrm{pH}$, low calcium concentrations, high groundwater temperatures and semi-arid climatic conditions of the study area likely contribute to high fluoride concentrations in groundwater, by increasing the solubility of fluoride-bearing formations and decreasing dilution effects due to rainwater.

The results of the questionnaire survey conducted in Siloam Village show that of the $87 \%$ of households that use groundwater, $85 \%$ have members with mottled teeth. $50 \%$ of school learners between the ages of 11-14 also have mottled teeth. Questionnaire survey results generally indicate that majority of residents of Siloam Village are aware of the presence of mottled teeth, its causes and treatment. This should facilitate education of residents to avoid ingesting high concentrations of fluoride by using only defluoridised water or avoiding the use of untreated groundwater for cooking or drinking.

\section{Acknowledgements}

The funding received from the former Department of Environmental Affairs and Tourism (DEAT) by the former Dean of the School of Environmental Sciences at the University of Venda, Prof Omara-Ojungu is gratefully acknowledged, as is the funding received from the Research and Publications Committee (RPC) of the University of Venda through the current Dean, Prof JS Ogola. The assistance of the students who participated in collecting the data, including Ms P Mashai, Ms A Ramudzuli and Mr L Nare is gratefully acknowledged.

\section{References}

ASHTON P, LOVE D, MAHACHI H and DIRKS P (2001) An overview of the impacts of mining and mineral processing operations on water resources and water quality in the Zambezi, Limpopo and Olifants catchments in Southern Africa. Report No. ENV-P-C 2001042. MMSD Southern Africa Research Reports, South Africa.

BAILEY K, CHILTON J, DAHI E, LENNON M, JACKSON P and FAWELL J (eds) (2006) Fluoride in Drinking Water. IWA Publishing (on behalf of the World Health Organization), London.

BOTHA FS and VAN ROOYEN JL (2001) Affordable water resources development in the Limpopo Province, South Africa. J. Afr. Earth Sci. 33 687-692.

CHAE GT, YUN ST, MAYER B, KIM KH, KIM SY, KWON JS, KIM $\mathrm{K}$ and KOH YK (2007) Fluorine geochemistry in bedrock groundwater of South Korea. Sci. Total Environ. 385 272-283.

CLARKE S (2000) High fluoride in the Namaqualand Area, Northern Cape. BSc Hons. (Geology) dissertation, University of the Western Cape.

CUMMING G, FIDLER F and DAVID LV (2007) Error bars in experimental biology. J. Cell Biol. 177 (1) 7-11.
DWAF (DEPARTMENT OF WATER AFFAIRS AND FORESTRY) (1996) South African Water Quality Guidelines, Vol. 1: Domestic Water Use ( $2^{\text {nd }}$ edn.). Department of Water Affairs and Forestry, Pretoria.

EDMUNDS WM and SMEDLEY PL (1996) Groundwater geochemistry and health: an overview. In: Appleton JD Fuge R and McCall HJG (eds.) Environmental Geochemistry and Health. Geological Society Special Publication No. 113. 91-105.

FEENSTRA L, VASAK L and GRIFFIOEN J (2007) Fluoride in groundwater: Overview and evaluation of removal methods. International Groundwater Resources Assessment Centre Report nr. SP 2007-1.

JACKS G, BHATTACHARYA P, CHAUDHARY V and SINGH KP (2005) Controls on the genesis of some high-fluoride groundwaters in India. Appl. Geochem. 20 (2) 221-228.

MADHNURE P, SIRSIKAR DY, TIWARI AN, RANJAN B and MALPE DB (2007) Occurrence of fluoride in the groundwaters of Pandharkawada area, Yavatmal district, Maharashtra, India. Curr. Sci. 92 (5) 675-679.

MASHAI NPD (2007) Monitoring fluoride concentrations and determining their impacts on human health at Siloam Village in Limpopo Province of South Africa, unpublished Honours research dissertation, University of Venda, South Africa.

McCAFFREY LP and WILLIS JP (2001) Distribution of fluoride-rich groundwater in the eastern and Mogwase regions of the Northern and North-West Provinces. WRC Report No. 526/1/01. Water Research Commission, Pretoria.

MOTULSKY H (2007) Prism 5 Statistics Guide Version 5.0. GraphPad Software Inc., San Diego CA.

NÄSLUND J and SNELL L (2005) GIS mapping of fluoride contaminated groundwater in Nakuru and Baringo District, Kenya: A minor field study. MSc Thesis, Lulea University of Technology, Sweden.

NCUBE EJ and SCHUTTE CF (2005) The occurrence of fluoride in South African groundwater: A water quality and health problem. Water $S A 31$ (1) 35-40.

NEZLI IE, ACHOUR S, DJIDEL M and ATTALAH S (2009) Presence and origin of fluoride in the complex terminal water of Ouargla Basin (Northern Sahara of Algeria). Am. J. Appl. Sci. 6 (5) 876-881.

ODIYO JO and MAKUNGO R (2009) Fluoride concentrations in groundwater, human health impact and possible remediation in Siloam Village, Limpopo Province, South Africa. Biennial Groundwater Conference, 16-18 November 2009, Somerset West, South Africa.

OLIVIER J, VAN NIEKERK HJ and VAN DER WALT IJ (2008) Physical characteristics of thermal springs in the Waterberg area of Limpopo Province of South Africa. Water SA 34 (2) 163-173.

RAJU NJ, DEY S and DAS K (2009) Fluoride contamination in groundwaters of Sonbhadra District, Uttar Pradesh, India. Curr. Sci. 96 (7) 975-985.

RIVETT M, DREWES J, BARRETT M, CHILTON S, APPLEYARD S, DIETER HH, WAUCHOPE D and FASTNER J (2006) Chapter b4. Chemicals: health relevance transport and attenuation. In: Schmoll O, Howard G, Chilton J and Chorus J (eds) Protecting Groundwater for Health: Managing the Quality of Drinking Water Sources. WHO Drinking Water Quality Series, IWA publishing, London.

SALKIND NJ (1997) Exploring Research ( ${ }^{\text {rd }}$ edn.). Prentice Hall, Upper Saddle River.

SAXENA VK and AHMED S (2003) Inferring the chemical parameters for the dissolution of fluoride in groundwater. Environ. Geol. 43 731-736.

VASAK S, BRUNT R and GRIFFIOEN J (2006) Mapping of hazardous substances in groundwater on a global scale. Chapter 6. In: Appelo $\mathrm{T}$ (ed.) Arsenic in Groundwater - A World Problem. Proc. Seminar, Utrecht, 29 November 2003. Netherlands National Committee of the IAH Secretariat, Utrecht.

WORLD HEALTH ORGANIZATION (WHO) (2000) Quality of Domestic Water Supplies. IWA Publishing, London, UK.

WORLD HEALTH ORGANIZATION (WHO) (2006) Guidelines for Drinking-water Quality ( $3^{\text {rd }}$ edn. incorporating the first addendum). Volume 1. Recommendations. World Health Organization, Geneva. 